I.9 per cent of the national income, compared with spending in Britain in the same year of $£ 750$ million $(2.9$ per cent). Of the total more than a quarter was spent by the vigorous chemical and chemical engineering industries. A survey in 1962-63 by the Japanese Ministry of International Trade and Industry showed that, in one sense, Japan is running at a deficit, spending more in royalties on foreign patents than she earns on her own patents; in 1964 the royalties paid on foreign patents amounted to nearly $£ 50$ million. Japan's defence estimates for 1966 are paltry in comparison with those of comparable countries ( $\$ 336$ million against nearly $£ 2,500$ million for the United Kingdom), but savings in defence do not seem to have released money for research. How has Japan managed to run a successful economy without the expenditure on science and technology which is nowadays regarded as a prerequisite?

The answer may be that Japan squeezes the maximum value out of each yen spent on research. An example of this is her admittedly unsophisticated space research programme, in which eight satellites are to be launched for a total cost of less than $£ 22$ million, spread over a long period of time. Somehow Japanese scientists have managed to carry out the programme at an annual expenditure of less than $£ 3$ million, and without the escalation of costs that has bedevilled British projects and joint European endeavours such as ELDO. In 1964 the outlay for each research worker in Japanese research was $£ 2,250$, the total budget of $£ 438$ million being divided among 195,000 research workers. This is a remarkably low figure, to be compared with a figure of about $£ 10,000$ per annum in the United Kingdom. While the figures may not be strictly comparable-it is not quite clear what definition of a qualified research worker is applied in Japan-they do indicate a wide disparity. It would seem that Japan maintains industrial momentum by an understanding of cost-effectiveness in research. There is no doubt, too, that in the short term the speed at which scientific research can be translated from the laboratory bench to the factory floor is more important than the volume of work in progress. There is, for example, a flourishing Japanese electronics industry.

\section{New Zealand Science}

Expenditure on science in New Zealand is increasing steadily, both absolutely and as a percentage of the Gross National Product. This is plain from the report of the National Research Advisory Council for the year ended March 31, 1966. The report says that expenditure has increased by a factor of $3 \cdot 2$ since the year ending in 1955 , although the increase in prices since then implies a real increase in expenditure by a factor of $2 \cdot 3$. During this period the number of scientific staff employed in government departments has increased by only 55 per

\begin{tabular}{|c|c|c|c|c|}
\hline \multicolumn{5}{|c|}{ Table 1} \\
\hline & $\begin{array}{c}\text { Actual } \\
\text { expenditure } \\
£(000)\end{array}$ & $\begin{array}{c}A s \\
\text { percentage } \\
\text { of G.N.P. }\end{array}$ & $\begin{array}{c}\text { Scientific staff } \\
\text { in government } \\
\text { departments } \\
\text { March } 31\end{array}$ & $\begin{array}{c}\text { Expenditure } \\
\text { at } 1966 \\
\text { prices }\end{array}$ \\
\hline $\begin{array}{l}1955 \\
1957 \\
1959 \\
1961 \\
1963 \\
1965 \\
1966\end{array}$ & $\begin{array}{l}2,733 \\
3,547 \\
4,110 \\
4,912 \\
5,759 \\
7,428 \\
8,709 *\end{array}$ & $\begin{array}{l}0.27 \\
0 \cdot 35 \\
0 \cdot 36 \\
0.38 \\
0 \cdot 40 \\
0 \cdot 42 \\
0 \cdot 46^{*}\end{array}$ & $\begin{array}{l}568 \\
592 \\
628 \\
684 \\
754 \\
819 \\
882\end{array}$ & $\begin{array}{l}100 \\
123 \\
133 \\
153 \\
172 \\
209 \\
233^{*}\end{array}$ \\
\hline
\end{tabular}

cent. Table 1 shows the actual expenditure on science in New Zealand in alternate years in the past decade (excluding sums of money spent on buildings). The table also shows the way in which the number of scientists employed in government departments has increased.

Of the total expenditure on science in the current financial year, the council estimates that 74 per cent will be spent by government departments, of which the Department of Scientific and Industrial Research takes slightly more than half. Universities spend $£ 800,000$, or between 8 and 9 per cent of the total in New Zealand on research.

As a result of a detailed review of research policy carried out in previous years, the council has recommended to the Government of New Zealand a considerable increase in the scale of building research, which is estimated to cost $£ 330,000$ in the current year and which will be increased by some 18 per cent in the course of the following three years. Advice for industry and research in transport are also to be increased, and an attempt is to be made to bring the meteorological service up to strength. Work at the Institute of Nuclear Sciences (of the Department of Industrial and Scientific Research) will be extended, principally by the purchase of a 20,000 -c. cobalt source.

\section{Foot in the Door}

THE Committee of Vice-Chancellors and Principals of England and Wales is delighted with a modest step towards rationalizing entrance requirements to universities now agreed upon by 29 out of 35 universities. The universities concerned have agreed to adopt one or other of two patterns of examination qualifications as a condition for university entrance. One pattern includes five passes in General Certificate of Education examinations, with at least two passes at the Advanced level; the other, intended to cater for students at technical colleges and other such institutions, involves four passes in GCE examinations, three of them at the Advanced level. Particular universities will continue to accept students with various other patterns of qualifications in GCE examinations but, apparently, the number of different patterns acceptable to the universities of England and Wales has been reduced from 19 a year ago to 9 this year.

The universities which have chosen to stand aloof are not all black sheep. In fact, the University of Lancaster requires less of intending university students than either of the two patterns now uniformly adopted. The Universities of Warwick, Keele and Exeter differ from the general pattern in requiring cither a language or English qualification from those wishing to become scientists. The universities of Oxford and Cambridge, predictably, have not yet modified their matriculation requirements sufficiently to conform with the general pattern, although there is optimistic talk that Cambridge is considering relaxing the requirements of two language qualifications for intending scientists.

None of this, of course, diminishes the strongest pressure of the universities on the schools-the way in which particular departments or faculties in British universities require particular subjects to have been studied at school by intending students. It remains possible for a student to satisfy entrance requirements 